\title{
FIRST INTERNATIONAL CONGRESS OF BIORHEOLOGY
}

\author{
POISEUILLE AWARD CEREMONY FOR A. L. COPLEY \\ Amphithéatre A, Université Claude-Bernard, Lyon, France, 5 September 1972
}

\section{ACCEPTANCE SPEECH}

\author{
AlFred L. COPLEY
}

New York Medical College, New York, N.Y. 10029, U.S.A.

\section{Mr. Chairman, Dr. Scott Blair, Ladies and Gentlemen}

I AM deeply moved by the great honor which the International Society of Biorheology has bestowed on me here at our I. International Congress. I am most grateful for the appreciation shown to me by my peers and I thank you all who have come to participate in this ceremony and to everyone in our young science who thinks so highly about my attainments and accomplishments. It makes me deeply grateful to you all and to my dear friend GeORGE SCOTT BLAIR who so eloquently, generously and warmly talked about me. It makes me particularly happy that he, as its previous recipient, placed the Poiseuille Medal on me. My thanks go equally to my friend Geoffrey SEAMAN, Chairman of this ceremonial event, for his kind words. I feel most humble, as our Society could have chosen others from our midst for this very great honor.

Yesterday in the morning, when we all met here at Lyon in the large auditorium of the Palais des Congrès, I gave, in my Inaugural Address, a historical account of our science of biorheology. Then, in the afternoon in the same hall, I delivered the lecture "On Biorheology", to which President, Professor VALLET and the members of the Organizing Committee of the VI. International Congress on Rheology kindly invited me to present before the Joint Plenary Sessions of both our Congresses. Today, at our Congress, we had a heavy program of three Plenary Sessions which ended a little while ago and which honored the memory of my dear friend AHARON KATZIR-KATCHALSKY. Aharon's portrait, mounted on a board by my daughter UNA DORA, has been thoughtfully placed by her in front of us on this table.

Three years ago GeORGe Scotr BLAIR delivered his Poiseuille Award Lecture at the Award Ceremony at the University of Heidelberg. I believe that in the future the Poiseuille Award Lecture should be a feature of this ceremony. I regret that there will be no such lecture at this event. However, you may consider the lecture "On Biorheology", which I gave at the Palais des Congrès yesterday, as the Poiseuille Award Lecture, although it cannot be designated as such. I suppose, you do not expect me to give a lecture or a long talk now. Instead, I should like to tell you merely the story how the Poiseuille Gold Medal Award came into being.

In 1965 I had to visit the American Institute of Physics, which is located in close vicinity of the United Nations Building in New York City on East 45th Street. After I left the Institute, I stopped, at a distance of a few houses from it, in front of a window display of medals. As I am curious about anything, which is formed in attempts to give visual pleasure, 
I entered the building, which houses a medal factory, to view numerous medals in its exhibition hall. I must say, I was appalled to see among them so many medals, designed in very poor taste, although manufactured with the finest craftsmanship and commissioned by many learned societies and other organizations of great distinction and esteem. My initial reaction to the many medals on display was, I am sorry to say, that of utter dislike. With a feeling of dismay, I left the building, reflecting on who of distinction would wish to have a medal of poor design.

When I continued my walk West on 45th Street, I was struck with the idea that it would be grand to have a medal coined as an award to be given to those who have greatly advanced our science. The name of JeAN-LÉONARD-MARIE PoIseuille immediately came to mind with the question after whom the medal should be named. Next came the question, and to me it was a very important one, who should be asked to design the medal? As I happened to know personally several of our finest artists in different countries, the questions then were, should the portrait of Poiseuille be a sculptured relief and whom should I ask to make the design? The more and more I thought about this, I came to the belief that it might be refreshing to depart from the generally accepted sculptured portrait of the person after whom the medal is named and apply something quite different to the face of the medal. I thought of a drawing to be cast in relief which would give a likeness of the features of Poiseuille. When I arrived at my home that day, I knew exactly whom to ask to draw such a portrait after a photograph, which I found in the archives at the Academie de Médecine during my stay in Paris from 1952 to 1957, as Geoffrey SeAman already mentioned.

The artist, whom I asked, was my wife, the painter NINA TRYGGVADOTTIR. I asked her, because she had done many fine portraits, although portraits were only a small part in her life's work as an artist. Nina was enthusiastic about my idea and she made many drawings from the photograph of the portrait of Jean-Léonard-Marie Poiseuille. One of these drawings GeOFFREY SEAmAn, my daughter and I selected several months ago for the cover of the booklet of abstracts of our Congress, while, 61 years earlier, Nina chose one of her drawings to be coined on the medal. She left space for a replica of the actual signature of Poiseuille which we asked our dear friend MAURICE JOLY to search for and which he fortunately found in Paris and sent to her. This signature has become part of the medal.

I am glad to say that this medal, with which I just have been honored so generously, represents one of the finest designs of a medal I have seen. I never thought that I ever shall be one of its recipients. I am happy to have received the Poiseuille Medal so unexpectedly, foremost, of course, for what it represents, then that it has been designed by my late wife, and that, in my appraisal, it also represents a fine piece of art.

I thank you very much! 